\title{
Heuristic Understanding as a Component of Collaborative, Interdisciplinary, Social Justice Advocacy Research
}

\author{
Stephanie Bauman, Michele Acker-Hocevar, and Danny Talbot \\ Washington State University - Tri-Cities
}

\begin{abstract}
This article describes the experiences of three university colleagues with a common interest in, and commitment to, the retention of students from traditionally underserved populations including those who are racial/ethnic minorities or first-generation college. Using Moustaka's (1990) phases of heuristic understanding as an organizational framework, we discuss our use of autoethnography to arrive at new understandings of ourselves as researchers and our area of inquiry. Consistent with social justice advocacy research, this research collaboration has the potential to inform efforts to empower traditionally underserved college students and to facilitate transformational change in an institution of higher education.
\end{abstract}

Keywords: college retention, social justice, autoethnography

\section{Introduction}

This article describes the experiences and evolving insights of three university colleagues with a common interest in, and commitment to, the retention of students from traditionally underserved populations including those who are racial/ethnic minorities or first-generation college. Our collaboration began with informal discussions about the dramatic demographic changes at the campus of the state university where we have worked. In a span of a few short years, there was a $57 \%$ increase in full-time equivalent students and a $147 \%$ increase in Latino students. Cognizant of the challenges of retaining diverse students and urgent need to address 
them (Nuñez, 2009; Stephens, Fryberg, Markus, Johnson, \& Covarrubias, 2012), we wanted to identify students' strengths and empower them to navigate barriers to academic persistence in college. We also wondered how we as faculty members could work on behalf of students and enhance their well-being by altering campus structures and practices. At their core, our concerns dealt with social justice advocacy in a college setting (Diemer \& Duffy, 2010). Consistent with calls to utilize interdisciplinary alliances and resources in efforts to advance social justice (Toporek \& Vaughn, 2010), we hoped that a strong research collaboration might lead not only to the integration of social justice in terms of our individual practice as educators in higher education, but also to concomitant changes on the organizational level as well.

Early in our work together, we questioned how our life experiences and professional perspectives influenced our conceptual ways of knowing and expectations about students, institutions of higher education, and retention. We tacitly acknowledged Crowley and Hawhee's (2004) assertion that researchers are a sum of their life experiences and education, and to ignore this complexity risks minimizing much of the richness in the research process. Arguably, researchers seldom have elaborated on this phenomenon beyond brief discussions of reflexivity (Denzin \& Lincoln 1994; Pillow, 2003). Similarly, in spite of calls for partnerships across disciplines, scholars infrequently have described their collaborative research experiences much less how they came together to work. Given this state of affairs, the postmodern research terrain has suggested inquiry strategies that offer richer and thicker descriptions of people and the complex phenomena surrounding them. This model has allowed researchers to engage in inquiry that looks at interactions and reflections in relation to self and the world in which the research questions are nested (Ellis, 2004; Ellis \& Bochner, 2000; Hassan, 1987; Stivers, 1993). For example, the inquiry strategy of autoethnography has acknowledged how the researcher's own experience can serve as an entry point for scholarly consideration (Chang, 2008; Ellis, 2004; Ellis \& Bochner, 2000; Hayano, 1979; Stivers, 1993). Moustakas (1990) referred to this self-investigation as heuristic research and explained, "I begin a heuristic investigation with my own self-awareness and explicate that awareness with reference to a question or problem until an essential insight is achieved, one that will throw a beginning light onto a critical human experience" (p. 11).

Moustakas (1990) described six phases of heuristic experience:

1. Initial passionate engagement occurs as questions to which the researchers are deeply committed begin to arise.

2. Immersion occurs when researchers look deeply into the issues of how to explore emerging questions.

3. Incubation happens as researchers' ideas germinate and grow while other pressing duties require their attention.

4. Illumination occurs when new conceptualizations and understandings around these issues surface as the researchers consider their unique and shared positionalities.

5. Explication takes place as new ways of looking at the research questions develop.

6. Culmination evolves as researchers' experiences and perspectives mingle with the new understanding to allow creative expression and greater understandings of the research.

Thus, while acknowledging that heuristic understanding is not necessarily tidy or orderly, we will use Moustaka's phases to discuss how we came to work together and how we used autoethnography to arrive at new understandings of ourselves as researchers and our area of inquiry. 


\section{Heuristic Understanding}

\section{Initial Passionate Engagement: Forming the Collaboration and Looking at Biases and Expectations}

Our work together began inauspiciously in the hallway outside of our offices; we sporadically conversed about the noticeable increase in the number of diverse students at the campus of the state university where we worked. After multiple discussions on the topic, it was clear we shared a common interest in facilitating the students' likelihood of academic persistence in college and enhancing the university's ability to retain them. Serendipitously, we had an opportunity to apply for seed money through the academic college in which we worked. Thus, we decided to form a research team. Our long-term goals included developing a theoretical framework to explain college student persistence, conducting an online survey of current students, and doing semi-structured interviews with students who were considered traditionally underserved.

When our scholarly collaboration began, we had been departmental colleagues for one year. One of us was connected to a counseling psychology program, while the other two were connected to an educational leadership program. We had some sense of each other after attending some of the same meetings and/or serving on various committees together. At the start, we were optimistic that our group dynamic would be a positive one. There was a shared commitment to mutual respect, equal involvement and shared power that was consistent with feminist and multicultural approaches to collaborative research (Hill, 2012).

Hill, Thompson and Williams (1997) suggested that qualitative researchers report both biases and expectations so that readers can evaluate the findings of a study with that knowledge in mind. Biases may arise from different demographic characteristics of the researcher and consist of the personal issues which make it difficult for researchers to respond objectively to the research data. Biases also are inherent in the values and beliefs about or feelings and reactions to the topic. In turn, expectations include the beliefs that may be formed based on reading professional literature. In order to provide information relevant to possible biases and expectations, demographic information and a brief discussion of the research interests of each member of our team follows.

Researcher $A$ is a European-American who is in her early $60 \mathrm{~s}$. She has lived in the Southeast, Midwest, and West. She received her undergraduate degree from a strong liberal arts college and her Ph.D. in Organizational Studies and Educational Leadership from one of the largest, urban, public universities in the United States. Researcher A's program of research centers on leadership and organizational development and change. She approaches her scholarship believing that it is critical to build on an additive versus subtractive social and cultural human resource perspective that disrupts social inequalities (Acker-Hocevar, Cruz-Janzen, Wilson, Walker, \& Schoon, 2206/2005; Acker-Hocevar \& Touchton, 2002).

Researcher B is a third-generation, Filipino-American woman who is in her mid-40s. She received her undergraduate degree from a private university in the Midwest and a Ph.D. in counseling psychology from a public university in the West. She is the daughter of parents who each were the first in their families to go to college. Researcher B's scholarship is informed by 
clinical experience as a counselor in university counseling center settings. Her research examines the utilization of personal and environmental sources of competence and wellness in response to risk-laden or stressful life circumstances or events (Bauman, 2002; Bauman, 2010; Bauman, Wang, DeLeon, Zavala-Lopez, \& Lindsay, 2004; Morrison, Laughlin, San Miguel, Smith, \& Widamin, 1997).

Researcher C self-identifies as an Anglo male, early sixties, who is a first-generation college student. He grew up in the rural West, and worked in agricultural jobs while growing up, often alongside migrant workers. He received his undergraduate degree in psychology and doctoral degree in Educational Leadership from a large urban western university. He focuses his scholarship on how people engage in sensemaking (Weick, 1995; Talbot, 2000; Ogawa, Johnson, Talbot, et al, 2002; Weick, Sutcliffe, \& Obstfeld, 2005) in an effort to be successful members of their organizations (e.g., schools), and how organizational change affects enactment of sensemaking strategies. His interests are connected by issues with social justice implications. In addition to work as a scholar, his experience includes extensive work as a teacher, principal, and superintendent in public school settings.

\section{Immersion: Writing the Autoethnographies}

As previously mentioned, two of our goals included theory building and conducting an online survey of underrepresented college students. We considered relevant literature from our respective fields of study and how everything might fit together. We also looked at the literature on college student retention. It became clear that we shared an ecological perspective; we saw human behavior as a function of person-environment interaction. We each thought it important to view people holistically and build on their strengths. We also shared a commitment to social justice advocacy in which growth and development occurs through the identification and alteration of personal and environmental factors (Greenleaf \& Williams, 2009; Vera \& Speight, 2003). Meanwhile, we wanted to remain open to learning about the student experience and recognized that qualitative research methods are well suited to the study of individual meanings in social contexts (Morrow, Rakhsha, \& Castañeda, 2001). Consequently, we made a decision to follow the survey with semi-structured interviews with students purposively sampled because they were first-generation college students and were of racial/ethnic minority backgrounds.

As we talked about our perspectives on student persistence and formulated related survey and interview questions, we often found ourselves sharing vignettes about students with whom we had worked. Moreover, we also shared stories about our own college experiences or about the experiences of family members and close friends. It occurred to us that prior to asking students to tell us about themselves, it would be helpful to understand ourselves better via autoethnography. We chose autoethnographies as the vehicle to tell our stories because we thought personal narratives would help each of us understand ourselves in intersection with our research and with each other. By combining self-search and self-dialogue, perhaps we could discover the deeper reasons why were interested in historically underserved students entering our institution and how we located our conceptions of self in relation to our study. Moreover, reflection on what we have learned over time in our life experiences and work, might inform how we conceptualized our main research questions, and how we designed studies involving student participants. Other than setting a target date for the completion of a first draft of an autoethnography, the task was unstructured in terms of both content and format. (See 
Appendix A for complete autoethnographies.) The overarching question for each of us was "Why am I interested in this study?" We began to write.

\section{Incubation: Discussing and Rewriting the Autoethnographies}

Moustakas (1990) describes the incubation part of the heuristic understanding process as the time when researchers' ideas germinate and grow while other pressing duties require their attention. Since our other responsibilities included teaching classes and advising our students to ensure timely degree completion, we had occasion to come across ideas and situations which were related to our research outside of our scheduled research meetings. When we did meet as a research team, we decided to discuss our first drafts of our autoethnographies. Bateson's (1989) observations about reading and writing biographies seemed to fit our experience with autoethnographies as well: "Each reading provokes a dialogue of comparison and recognition, a process of memory and articulation that makes one's own experience available as lens of empathy" (p. 5).

We agreed to be open to editing and revising our respective autoethnographies. A variety of questions had arisen after reading and discussing the autoethnographies. To what groups did each of us feel connected? Given that each of us had multiple identities, some identities were more proximal and others more distal to our scholarly interest in traditionally underserved college students. What specific aspects of identity were most salient at different points in our autoethnographies? How did we experience privilege, oppression or both? Moreover, how did that impact our sense of self? When did we realize that we were part of a community and that there was a relationship between our individual well-being and community well-being? Did this awareness of the responsibility to others impact our personal and professional choices and decisions? In retrospect, it seemed that much of what we grappled with involved the recognition of multiple identities; awareness of our positions as privileged, oppressed or both; and awareness that the self is socially connected and capable of social change (Hurtado, 2010; Yakushko, Davidson, \& Williams, 2009).

\section{Illumination: Analyzing the Autoethnographies}

In the heuristic understanding process, illumination occurred when we tried to more deeply consider our unique and shared positionalities in order to inform new conceptualizations and understandings around issues of the college experience. We accomplished this through a thematic analysis of our revised autoethnographies. One member of the research team volunteered to create a tentative list of themes, and through a series of e-mail exchanges followed by an in-person meeting we arrived on the themes which represented our common understanding of the data. The themes were: moving from outsider to insider, journey to new places, temporal fusions and reinventing self.

\section{Moving from outsider to insider}

Our stories helped us to see that each of us is more of an insider to a study of historically underserved college students than we originally thought. Author B told her mother's story of being a first-generation college student. She reflected on her mother's choice to temporarily separate from her Hawaiian friends and live and study with European-American classmates to master "standard" English. Author A related how her 
grandmother had come to the United States and had to learn the language and culture to survive as she, at the formative age of fourteen, was the only one in her immediate family to leave Norway. Drawing connections to the agricultural workers in the community where he currently lives and works, Author C spoke of how he had worked in the fields as a young person and could see the sacrifices of one generation to the next that made way for him to be first person in his family to attend college.

Each of us realized the importance of self-awareness in the process of making sense of and adapting to an institution of higher education. Author B related how she went to college at a selective private university and had to make sense of her life in relation to her two roommates from diverse socioeconomic and racial/ethnic backgrounds. Yet, one thing she and her roommates all held in common was their desire to graduate from an institution where they each had experienced connection and belonging. Author A talked about how she was unable to relate to the Puerto Rican students that asked her questions because she had no knowledge of their culture and language-she stayed on the outside. Author $\mathrm{C}$ explained how his students who could be categorized as underserved were his best teachers about learning about different people and their life experiences. Each story acknowledged that to understand another person, you have to be willing to enter their language, culture, and experiences.

\section{Journey to new places}

Each of us related how we watched others or ourselves journey to new places. During these journeys, the landscape was both familiar and unfamiliar. Author $\mathrm{C}$ talked about looking at the surrounding hills and remembering similar experiences of working in the orchards while he was growing up. Author B was clear that her mother had to be willing to be a risk-taker and interact with a wider circle of friends in college. Author A saw the process of journeying to new places as a life time of travels that were bound by how one interprets and re-interprets one's stories after each life-altering event.

Not everyone, however, is willing to journey to new places. Author A's great grandmother placed herself in a superior position over others, relegating them to subordinate positions. Both Author B and Author A saw how the historical backdrop of time and place influenced a person's sense of self and willingness to travel to new places. Even more so, a person's willingness to question and possibly even let go of what they had been carefully taught was the result of either love and/or education across the stories. The extension of a helping hand enabled the people in our stories to travel to new places. New opportunities presented themselves, as in the case of Author B's mother who used money left to her by a brother killed in the Korean War to pursue higher education or Author A's grandmother whose father arranged a new life for her in America after she was rejected at birth by her Norwegian mother. In turn, Author C noted how he created the space for his students to talk openly about their experiences, extending a helping hand to legitimize the notion that all journeys are valued. 


\section{Temporal fusions}

The way that each of us related to the study of first-generation college students was inextricably connected to how we each positioned ourselves in time and space. These temporal fusions represented memories that linked to what each of us thought was important to bring to the forefront of our story for this work. The individual time orientations laid directly beneath the surface of our stories and revealed something interesting about how each of us represented these past and/or present events as memories across time. For Author A the sense of events imparted in family traditions and lore intertwined with world events, and social and cultural mores of the day. She pieced her insights together like a puzzle to see where she fit. Like her mother, Author $\mathrm{B}$ was a risk-taker. There was a strong and present awareness of how her past influenced her decision to push the boundaries even further than her parents by attending a prestigious university and to going to graduate school. As a teacher and advisor, she has tried to advocate that students push growth edges of their own too. Author $\mathrm{C}$ viewed his experiences through the natural world around him such as the land, river, and local fauna and his relationships with others and self. His story, more present-oriented than past, more connected to the natural world than day-to-day events, brings his journey home to collapse in on itself, like a black hole, revealing a lifetime pursuit of working with disadvantaged students and families that seemed to surprise him. He blended literature and life experiences to capture the broader human experience that framed each of these stories and punctuated the importance of understanding the whole of life experiences to derive deeper meaning. Importantly, each story was meaningless without the context in which it unfolded and the sense of history in which it took place.

\section{Reinventing self}

As we read through each other's stories, we could see how we were reinventing ourselves through this process of reliving our stories and reading and listening to each other's stories. The stories included examples of risk-taking, personal courage, confronting prejudice, identifying status and power differences, and choosing role models to emulate and principles we wanted to accept or reject. Our identities were more fluid than we thought, not fixed in time and space but subject to how we interpreted new experiences that helped us define and shape our sense of self. Like an unfinished portrait, new information added to its completion.

\section{Explication: Using Autoethnography to Inform our Research}

After drawing on our life experiences and stories, we addressed this question: "How did our research project unfold in ways that were informed by our autoethnographies?" First, in the process of writing and discussing our autoethnographies, we individually and collectively shifted our perceptions of ourselves as doing a study on other people to being part of the research itself. We could relate in more ways than we initially realized to the idea of being first to go to college or first in some other way and what this meant in making sense of a new place or experience. Second, we were reminded of the power of stories. Morrow, Raksha, and Castañeda (2001) noted, ". . . presenting research results in storied form provides results that are powerful, true to the meaning of participants, and accessible to those whose lives are under 
investigation" (p. 586). Although we always had planned to do interviews, after the thematic analysis of our autoethnographies, we revisited our interview questions to ensure that students had ample opportunities to tell their stories to us. Reflecting on how our own stories revealed the helping hands which assisted in border crossings to new places, we included questions about what and who helped students to be successful in college and make sense of a four-year university. Undoubtedly, we found our own stories illuminated our passion and reason d'être into the field. Just as we have been changed by telling our stories and hearing each other's stories in turn, we will be further changed because of the stories we hear from the students.

Our curiosity has grown about how telling and constructing stories may enhance the college experience in a way that empowers traditionally underserved college students. Indeed, constructing stories about one's life as one develops is a process through which a student may integrate past experiences, current concerns and future prospects (Erikson, 1968; McAdams, 2001). We recognize that student stories will develop more fully over time. However, their stories represent what they know now and there is power in their stories. This power is not only in understanding a student's perspective, but also in realizing the value of telling the story so that it stays fluid. Strengths can be identified more easily, connections made to other stories, and commonalities interpreted. Moreover, it is possible that the process of storytelling itself could be an intervention that enhances social-belonging and increases student persistence. As an interesting case in point, Walton and Cohen (2011) recently tested a brief intervention aimed at strengthening first year college students' sense of social belonging in school. Participants in the treatment condition of the study read a report of a survey of more senior students at the school that included quotes about their experience. Initial "fish-out-of water" worries were represented as common and transient, rather than a sign that students were not college material. Participants were then asked to write an essay describing how their own experiences echoed the results of the survey. They turned their essays into videotaped speeches which, they were told, would be shown to future students to help ease other students' transition to college. Over a 3-year observation period, the intervention raised interventiontreated African-American students' grade-point average and self-reports of well-being relative to control groups.

We also see potential benefits in close self-examination on the part of institutions of higher education and the administrators and faculty in their employ. Stephens and colleagues (2012) present a compelling argument that institutions of higher education reproduce inequity when their unwritten norms, ideas and practices align with middle and upper-class cultural norms. Moreover, after surveying college administrators from first-tier national universities and liberal arts colleges, Stephens et al. found that many American universities emphasize independence when defining student success when many first-generation college students value interdependence. The resulting cultural mismatch may contribute to the achievement gap observed between first-generation college students and their continuing-generation peers. As this example demonstrates, examination of beliefs about the college experience has the potential to reveal unstated norms. Insights revealed from self-assessment as well as from student stories would likely facilitate the expansion the narrative into a more expansive story of "us" and the creation of more inclusive and equitable university structures and practices. 


\section{Culmination: Sharing Some Final Thoughts}

In the culmination phase of heuristic research, how researchers' experiences and perspectives mingle with the new understanding to allow creative expression and greater understandings of the research issues comes into focus (Moustakas, 1990). We began this work as a crossdisciplinary team by drawing on our unique research and scholarly strengths, and we moved from outsiders to insiders, realizing our life journeys reflected a self under construction and reconstruction. The heuristic experience (Moustakas, 1990) immersed us in our autoethnographic accounts and provided an incubator for our ideas about theory and research methods and social justice issues as they pertain to diverse students. As researchers, we learned that self-examination as well as the insights facilitated by scholarly collaboration bring a level of clarity to research and are well-worth the investment. Each of us believes now we will conduct a more meaningful study with first-generation, traditionally underserved, college students because of our heuristic understanding.

\section{Contact information:}

Stephanie Bauman, Ph.D.

Department of Educational Leadership and Counseling Psychology

Washington State University - Tri-Cities

Email: sbauman@tricity.wsu.edu

\section{References}

Acker-Hocevar, M., Cruz-Janzen, M.I., Wilson, C.L., Schoon, P., \& Walker, D. (2006/2005). The need to reestablish schools as dynamic positive human energy systems that are non-linear and self-organizing: The learning partnership tree. International Learning Journal, 12(10), 255-267.

Acker-Hocevar, M. \& Touchton, D. (2002). How principals level the playing field of accountability in Florida's high-poverty/low performing schools, Part III: Effects of high-poverty schools on teacher recruitment and retention. International Journal of Educational Reform, 11(4), 334-346.

Bateson, M. C. (2010). Composing a further life: The age of active wisdom. New York: Alfred A. Knopf.

Bauman, S. S. (2002). Fostering resilience in children. In C. L. Juntunen and D. R. Atkinson (Eds.) Counseling across the lifespan: Prevention and treatment (pp. 41-55). Thousand Oaks, CA: Sage. 
Bauman, S. S. (2010). School counselors and survivors of childhood cancer: Reconceptualizing and advancing the cure. Professional School Counseling, 14, 156-164.

Bauman, S. S., Wang, N., DeLeon, C. W., Kafentzis, J. Zavala-Lopez, M., \& Lindsey, M. S. (2004). Nontraditional students' service needs and social support resources: A pilot study. Journal of College Counseling, 7, 13-17.

Chang, H. (2008). Autoethnography as method. Walnut Creek, CA: Left Coast Press.

Crowley, S., \& Hawhee, D. (2004). Ancient rhetorics for contemporary students, (3rd ed.).New York: Longman.

Denzin, N. K., \& Lincoln, Y. S. (1994). Entering the field of qualitative research. In N. K. Denzin \& Y. S. Lincoln (Eds.), Handbook of qualitative research, (pp. 1-17). Thousand Oaks, CA: Sage.

Diemer, M. A., \& Duffy, R. D. (2010). Advocacy in college and university settings. In M. J. Ratts, R. L. Toporek, \& J. A. Lewis (Eds.), ACA advocacy competencies: A social justice framework for counselors, (pp. 119-128). Alexandria, VA: American Counseling Association.

Ellis, C. (2004). The Ethnographic I. Walnut Creek, CA: Alta Mira.

Ellis, C., \& Bochner, A. P. (2000). Autoethnography, personal narrative, reflexivity. In N. K. Denzin \& Y. S. Lincoln( Eds.), Handbook of qualitative research (2nd ed., pp. 733- 768). Thousand Oaks, CA: Sage.

Erikson, E. H. (1968). Identity: Youth and crisis. New York: Norton

Goleman, D., Boyatzis, R. E., McKee, A., (2002). Primal leadership: Realizing the power of emotional intelligence. Boston, MA: Harvard Business School Press.

Green, D. (2006). Historically underserved students: What we know, what we still need to. New Directions for Community Colleges, 135, 21-28.

Greenleaf, A. T., \& Williams, J. M. (2009). Supporting social justice advocacy: A paradigm shift towards an ecological perspective. Journal for Social Action in Counseling and Psychology, 2, 114.

Hassan, I. (1987). The postmodern turn: Essays in postmodern theory and culture. Columbus: Ohio State University Press.

Hayano, D. M. (1979). Auto-ethnography: Paradigms, problems, and prospects. Human Organization, 38, 113-120.

Heifetz, R. A. (1994). Leadership without easy answers. Cambridge MS: Belknap Press. Henderson, N., \& Milstein, M. (2002). Resiliency in schools-making it happen for students and educators. San Francisco, CA: Corwin Press. 
Hill, C. E. (2012). Consensual qualitative research: A practical resource for investigating social science phenomena. Washington, DC: American Psychological Association.

Hill, C. E., Thompson, B. J., \& Williams, E. N. (1997). A guide to conducting consensual qualitative research. The Counseling Psychologist, 25, 517-572.

Hurtado, A. (2010). Multiple lenses: Multicultural feminist theory. In H. Landrine, N. Russo (Eds). Handbook of diversity in feminist psychology (pp. 29-54). New York: Springer Publishing Company.

Kagan, J. (1994). Yesterday's premises: Tomorrow's promises. In R.D. Parke, R. A. Ornstein, J. J. Rieser, \& C. Sahn-Waxler (Eds). A century of developmental psychology (pp. 551-568). Washington, DC: American Psychological Association.

Kuo, J., Hagie, C., \& Miller, T. (2004). Encouraging college student success: The instructional challenges, response strategies, and study skills of contemporary undergraduates. Journal of Instructional Psychology. 31, 60-67.

Maestas, R., Vaquera, G. S., Zehr, L. M. (2010). Factors impacting sense of belonging at a Hispanic-Serving Institution. Journal of Hispanic Higher Education, 6, 237-256. doi:10.1177/1538192707302801

Matthews, J.L. \& Crow, G.M. (2010). The principalship: New roles in a professional learning community., Boston, MA: Allyn \& Bacon.

McAdams, D. P. (2001). The psychology of life stories. Review of General Psychology, 5, 100122.

Miller, P. H. (2006). Contemporary perspectives from human development: Implications for feminist scholarship. Signs: Journal of Women in culture and Society, 31, 445-469.

Morrison, G. M., Laughlin, J., San Miguel, S., Smith, D. C., \& Widamin, K. (1997). Sources of support for school-related issues: Choices of Hispanic adolescents varying in migrant status. Journal of Youth and Adolescence, 26, 233-252.

Morrow, S. L., Rakhsha, G., \& Castañeda, C. L. (2001). Qualitative research methods for multicultural counseling. In J. G. Ponterotto, J. M. Casas, L. A. Suzuki, \& C. M. Alexander (Eds.), Handbook of multicultural counseling, ( ${ }^{\text {nd }}$ ed.), pp. 575-603. Thousand Oaks, CA: Sage.

Moustakas, C. (1990). Heuristic research: Design, methodology, and applications. Newbury Park, CA: Sage.

Nuñez , A. (2009). A critical pardox? Predictors of Latino students' sense of belonging in college. Journal of Diversity in Higher Education, 2, 46-61.

Ogawa, R., Johnson, B; Talbot, D, et al (2002, April). Enactment Theory \& Karl Weick. A panel presented at the annual American Educational Research Association meeting, New Orleans, LA. 
Pillow, W. S. (2003). Confession, catharsis, or cure? Rethinking the uses of reflexivity as methodological power in qualitative research. Qualitative Studies in Education, 16(2), 175-196.

Reason. R. D. (2003). Student variables that predict retention: Recent research and new developments. NASPA Journal, 40 (4), 172-91.

Schein, E. H. (2004). Organizational culture and leadership ( $3^{\text {rd }}$ ed.). San Francisco, CA: Jossey-Bass.

Schoorman, D. \& Acker-Hocevar, M. (2010). Viewing faculty governance within a social justice framework: Struggles and possibilities for democratic decision-making in higher education. Equity \& Excellence in Education, 43:3, 310-325. doi:org/10.1080/10665684.2010.494493

Senge, P. (1990). The fifth discipline: The art and practice of the learning organization. NY: Currency Doubleday Press.

Shields, V. R., \& Dervin, B. (1993). Sense-Making in feminist social science research: A call to enlarge the methodological opinions of feminist studies. Women's Studies International Forum, $16(1), 65-81$.

Snyder, K. J., Acker-Hocevar, M. \& Snyder, K. M. (2008). Living on the edge of chaos Leading schools into the global age. ( $2^{\text {nd }}$ ed.). Milwaukee, WI: American Society for Quality (ASQ).

Stacey, J. (1991). Brave new families: Stories of domestic upheaval in late twentieth century American. New York: Basic books.

Stegner, W. (1955). Wolf Willow, A history, a story, and a memory of the last plains frontier. New York. Viking Press, p. 12.

Stephens, N. M., Fryberg, S. A., Markus, H. R., Johnson, C. S., \& Covarrubias, R. (2012). Unseen disadvantage: How American universities' focus on independence undermines the academic performance of first generation college students. Journal of Personality and Social Psychology. Advance online publication. doi:10.1037/a0027143

Stivers, C. (1993). Reflections on the role of personal narrative in social science. Signs: Journal of Women in Culture and Society, 18(2).

Syed, M. (2010). Memorable everyday events in college: Narratives of the intersection of ethnicity and academia. Journal of Diversity in Higher Education, 1, 56-69.

Syed, M. \& Azmitia, M. (2009). Longitudinal trajectories of ethnic identity during the college years. Journal of Research on Adolescence, 19, 601-624.

Talbot, D. L. (2000). Out with the old, in with the new: Principal succession at Liberty High. The Journal of Cases in Educational Leadership, 3(1), 12-18. 
Toporek, R. L. \& Vaughn, S. R. (2010). Social justice in the training of professional psychologists: Moving forward. Training and Education in Professional Psychology, 4, 177-182.

Tinto, V. (1997). Colleges as communities: Exploring the education character of student persistence. Journal of Higher Education, 68(6), 599-623.

Vera, E. M., \& Speight, S. L. (2003). Multicultural competence, social justice, and counseling psychology: Expanding our roles. The Counseling Psychologist, 31, 253-272.

Walton, G. M., \& Cohen, G. L. (2011). A brief social-belonging intervention improves academic and health outcomes of minority students. Science, 331, 1147-1451.

Weick, K. (1988). Enacted sensemaking in crisis situations. Journal of Management Studies, 25, 305-317.

Weick, K. (1993). The collapse of sensemaking in organizations: The Mann Gulch disaster. Administrative Science Quarterly, 3: 628-652

Weick, K. (1995). Sensemaking in organizations. Thousand Oaks, CA. Sage.

Weick, K, Sutcliffe, \& Obstfeld (2005). Organizing and the Process of Sensemaking. Organization Science, 16(4), August.

Yakushko, O., Davidson, M. M., \& Williams, E. (2009). Identity salience model: A paradigm for integrating multiple identities in clinical practice. Psychotherapy: Theory, Research, Practice and Training, 46(2), 180-192. Doi:10.1037/a00160680.

Zis, S. (2002). Changing student characteristics: Implications for new student orientation. Journal of College Orientation and Transition, 10(1), 64-68.

\section{Appendix A}

\section{Autoethnography I: Researcher A}

As I begin my story, I note how my scholarly work has centered on leadership and organizational development and change. I reflect on how some organizations use their human capital from an additive perspective versus a subtractive one (Acker-Hocevar, Cruz-Janzen, Wilson, Schoon, \& Walker, 2006/2005). I am acutely aware of how small changes in the external environment may have the potential to produce dramatic effects on the internal organizational environment (Snyder, Acker-Hocevar, \& Snyder, 2008). These changes can be threatening because they may alter power relationships in human systems that can de-center taken for granted assumptions and privileged ways of knowing. Although life is never static, being able to adapt and learn from what is happening around you is critical to individual and organizational sustainability and 
improvement. It is not always easy to pay attention. There are multiple challenges and interruptions that individuals and organizations must face. Critically, how well individuals and organizations learn to manage and respond to problems can mediate their successes. Just as some individuals are more adaptive and resilient than others, so too are some individuals and organizations better able to respond to challenges and changes in their environment (Heifitz, 1994; Henderson \& Milstein, 2002).

Presumably, more adaptive individuals and organizations have built capacity over time to take individual and collective actions to guide their decisions. Supportive and strong mental models can inform future actions and decisions and re-create the possibility for new ways of thinking and acting (Senge, 1990). I have learned from my work in faculty governance that staying poised for what may be possible requires listening systems that provide access to rich information and connections with others (Schoorman \& AckerHocevar, 2010).

As I enter this study, I begin to recount some past and vivid experiences that seem to blur together across time and space. I work hard to interrogate how these experiences are important to this study. Telling my story through autoethnography might deepen my understanding of self, might help me to explicitly identify common patterns across these experiences and enable me to draw inferences across our shared stories that better inform the heuristics of this study. According to Goleman, Boyatzis, and McKee (2002), resonant leadership allows a person to build common ground with others. Through selfawareness, self-management, and empathy, a leader can seek tighter connections with others, but in the process the leader needs to understand him or her "self."

As I mull over my many life experiences to select what I think are the most impactful memories, a mosaic of learning begins to take shape that was once invisible to me in relation to this study. Maybe some of these experiences can help me see what I hold in common with these students and my co-researchers after all. Unraveling these tightly knit threads of memories might reveal some unexpected feelings, questions, and thoughts that can trigger insights through this process. I want to be open but I am unsure of what I might find out, yet I am eager to begin.

Perhaps, if I understand how hard it is to look back into myself, I will see more readily the limitations of this type of research and its benefits. Bottom line, this undertaking fuses past memories to bridge "the remembered past with the anticipated future" (Ellis \& Bochner, 2000, p. 546). If this process does shed light, as Moustakas (1999) promises, then I should begin to discover in myself what I bring to this table as a researcher and as a human being. Through my individual story I can begin to unearth how my experiences might connect to the bigger picture of this research, resonate with my colleagues' stories and experiences, and enlighten my work in this study. What might our collective stories reveal about our common and unifying threads? I begin with my story.

\section{Carefully Taught}

One night I get up after struggling for over an hour or so to go back to sleep; I walk into the living room where I turn on the television. As I hit "Guide," a selection on the 
remote, I quickly scan through the channels, I find South Pacific. This is a Broadway show from the late 40 s and early 50s that takes place on one of the islands in the South Pacific during World War II. It was recently staged and performed at the Lincoln Center. As I listen to the music, I think of my dad and many other World War II vets, men of that era, who never wanted to talk about the war. My dad used to say when I asked him questions, "War is a horrible thing. It brings out man's inhumanity to man. That is all you need to know. I don't want to talk about it."

As I listen to songs from South Pacific, I am swept back to my childhood and the house we lived in Fargo, North Dakota; I was in primary school; it was in the 50s. As I visualize the wood cabinet stereo in our California-styled house and modern living room, I hear the record playing and one of the songs from South Pacific. Tears roll down my face. Has my sadness of my 90 year-old dad's recent placement in a nursing home made me feel maudlin? Am I crying because these songs remind me of my handsome and young dad singing "Some Enchanted Evening," as we gathered around the piano where either my mother or my grandmother played the piano? I was probably twirling around the living room dancing. What is it? Then I remember this study. While watching South Pacific, a young nurse who has fallen in love with a Frenchman whose Polynesian wife has died, leaving him with two young children of mixed race to bring-up, sings about how "you have to be carefully taught." The song strikes a chord with this study. You see, the young nurse explains in song to the Frenchman, right after meeting his two young children, why she cannot marry him. She explains she has been "carefully taught" to hate, fear, and turn away from others who are different. She flees his home telling the Frenchman she grew up in Little Rock, Arkansas. But she returns later, because in the end she questions how she was carefully taught.

\section{A Sense of Place, Time, and Self}

What is it about where we grow up, the places and the time, the stories, and how we are carefully taught? My dad grew up in Fargo, North Dakota and my mother grew up in a town about an hour away in Minnesota. Both of my parents were college graduates. In fact, my grandmother was a college graduate on my mother's side. You see, college was assumed in my family. Not so with my paternal grandmother. In fact she came to the USA from Norway to escape the prejudice in her family. She looked like her great grandfather who was a Tartar, a mercenary soldier fighting for the Swedes against the Norwegians. And so the story goes that my great, great grandfather was injured and hid away in my great, great grandmother's barn. My great, great grandmother married him after nursing him back to health.

When my grandmother was born, she was dark, had almond shaped eyes, and very dark hair; she was rejected at birth by her mother. Her father eventually sent her to Minnesota to live with his brother who was a Lutheran minister. She was the only child sent away and was the eldest of nine siblings. My grandmother's stay was short-lived with her uncle because he and his wife returned to Norway after only a year, leaving my grandmother to fend for herself. My grandmother, Ingaborg, had to learn to survive. She never wanted to talk about Norway with me or even speak Norwegian. She was in her 60 s before she ever returned to Norway for a visit but she used to write to her 
youngest sister in Norwegian. Her story is family lore in Norway, but I did not know that at the time I was growing up.

My grandmothers were both strong women with different stories. My mother's mother grew up in western North Dakota and was a middle child, the daughter of a German doctor who had left Wisconsin to come to the Dakota Territory to practice medicine during his spare time. He married my great grandmother who was from Rochester, Minnesota. What I mean is that my great grandfather was more interested in discovering oil, silver, and gold than actually practicing medicine. Although riches never materialized and he went through my great grandmother's family fortune, he was close to discovery on several occasions. My mom told me that my great grandmother never begrudged these various explorations. She loved my great grandfather.

\section{Identity, Power, and Knowing}

I never understood why my maternal grandmother referred to some of the Germans in western North Dakota as "German Russians." This seemed pejorative to me, like a "bad" thing to be. I was uncomfortable and used to ask her what she meant. She would say, "German Russians are not the same Germans who came here from Germany. They are Germans who went to Russia during the time of Catherine the Great to be farmers." So, I would wonder, what is wrong with that. I recently asked my mother what she meant by this. Later, when I was in Israel and an older man spoke to me in German, I was indignant. "I am an American. I am not German. I don't speak German." Every morning at breakfast he would say the same thing. He was in his 80 s and must have forgotten the previous conversation from the day before. Still, and with my grandmother, I did not understand the meaning behind what she was saying to me about German Russians so I constructed my story. To me, Germans were the ones that created concentration camps and killed six million Jews. I remember vividly when I saw the Holocaust story on television. I was in the sixth grade. This is also the same time that I asked my dad about the war. He had been at Auschwitz and had helped to liberate the camp survivors. I did not want to be German. In fact, my dad told me a story about our relatives in Norway he heard from his mother. Our relatives were part of the Underground Railroad that helped Jews escape from Germany. That is what I wanted to be, part of an Underground Railroad. I did not know that story when I visited the Holocaust Museum in Jerusalem and stopped at a plaque to commemorate all the Norwegian Freedom fighters. The plaque marked a tree planted in their memory. I was deeply moved by this but did not know why at the time. Then I heard the story from my father after I shared my emotional experience with him from seeing the plaque.

One of the pictures I have in my office is of my mother holding me standing next to my grandmother, my great grandmother, and my great-great grandmother. This picture symbolizes to me all the women in my life who have in some way influenced who I am today.

I want them close to me. I remember very little about my grandfathers. Both died young; one from a heart attack and the other from a stroke. I do however, remember my great grandfather who was the German doctor because he lived to be in his $90 \mathrm{~s}$. He always wore a suit, even if he was fishing at the family lake home where I spent every 
summer while I was growing up. He adorned a bow tie, vest, and one of those watches with a chain that hung from his vest. I did not realize while I was maturing how many German and Scandinavian ways of being I was exposed. I learned from my travels and reflections about how my identity construction was influenced by both the family Norwegian and German cultures and traditions. They had oozed into my being, mostly without fanfare or overt knowledge. It occurred to me as I unraveled these stories, that through my education, my travels, and my deep reflections, how complicated this all is. I wondered which stories were still incomplete, wrong, or missing vital information. It seemed more and more that unless we did undertake our personal journeys of selfdiscovery, we could be influenced by things that we did not choose for ourselves. Why should my story be anything but my story that I thoughtfully constructed?

When I went to Norway for the first time, I heard the story about my grandmother and understood her better. I found out that Ingaborg was the second child born to her parents. She was named after Ingaborg I, or the child that died before she was born. Ingaborg I had blond hair and blue eyes. Her father, dismayed by his wife's rejection of Ingaborg II, my grandmother, wanted my grandmother to have a better life. My Norwegian relatives told me that this is why my great grandfather arranged for my grandmother's passage to New York to travel from there to Minnesota to be with his brother and his wife.

\section{Coming Together or Remaining Separate}

During my travels, I learned how my upbringing was in-line with the Nordic perspective of seeing everyone as an equal, of not placing oneself ahead of another person. I also learned that my summers at "the lake" were how Norwegians spent their summers too. How strange to make these connections in my late 40s. Oh, and my maternal side, I surmised that my grandmother learned the term "German Russians" from her parents or my great grandparents. Where else? My mother related to me that my grandmother had modeled herself after my great grandmother who looked down on the German Russians because she felt superior. My great-grandmother came from Rochester and was an outsider. This made me think of how outsiders can chose to position themselves in relation to others. My great-grandfather did not feel similarly according to my mother. My mother also told me that my great-grandmother expressed this superiority because of the differences in the German language; she spoke a different dialect of German than the German Russians. In some ways, I too knew what it was like to feel displaced. I left the West after high school but my displacement was not about the language.

I went to college in the South in the early 70s from Montana. It was culture shock. So what did I do? I got married much too young and insisted that my new Southern husband move into an all Black neighborhood to further integrate the South. It was a condition of my accepting his marriage proposal. For some reason, I am now embarrassed at this naïve notion that I could right all the wrongs of past racism. When my husband and I moved into our new house, one of my neighbors told me, "We were really upset when we found out that white folks were moving in here but y'all have turned out to be o.k." I learned a lesson about only seeing the world through my eyes and getting married to someone I did not understand. 
After I received my Ph.D., I was asked to interview at a highly respectable Northeastern University. A student group of Puerto Rican students interviewed me and asked me what I knew about Puerto Ricans. I did not know anything. I was extremely uncomfortable and I worried that whatever I would say would be wrong. I wish now that I could have shared how I felt instead of trying to find the textbook answer to the questions they asked. If only I could have begun to make connections with these students. I could have started by listening to their stories about who they were and begun asking them to elaborate on their backgrounds and experiences. I actually shrink into my computer chair now as I write about this. My face tightens and my stomach hurts reminding me of how uncomfortable I felt at the time.

I had an epiphany when I was on sabbatical a couple of years ago. I traveled from Florida to spend time with my aging parents out West. As I was returned home, I told this stranger on the plane how far I had journeyed from where I had come concerning what I had been "carefully taught." I realized I was not my parent's story. I understood for the first time how their time and place and life experiences had shaped them; I had travelled, however, to new places and yet my story was intertwined with theirs. I also knew that I had intentionally placed myself in uncomfortable situations. Through my working with others from different backgrounds and cultures, my travels, and my education, I had learned about myself and exposed my own sense of white privilege and ignorance. I understood why I wanted to conduct this study. I wanted to continue learning about myself in relation to others' stories. I wanted to know more about how to make connections to that Underground Railroad that offers a helping hand. But I didn't want to think that I had the answers or that I was on some sort of mission. No, I had learned that lesson.

\section{En Route: Journeying to New Places and Insights Gained}

Maybe life is really about our collective journeys of self-discovery and how we craft our own stories. Maybe questioning the things we have been carefully taught and letting go of things that no longer work for us is part of the human experience. As I think about the family traditions and lore, I realize how my journey parallels others' journeys. I wonder how these students will negotiate their travels to new places because it seems that we shed part of the self that no longer works for us as we travel to new places. That isn't necessarily bad. Isn't learning and adaptation part of the human experience for each of us? The real journey is the inner journey where we each displace the old self to make room for an emerging self.

I see now that what I have learned as I was growing up shaped my early perspectives, even if I did not have the complete story. Self-discovery and journeying to new places has been a continuous re-storying of my life as new information and experiences disrupted past interpretations and offered fresh insights.

I resolve to myself writing this that knowing myself and telling this story makes me more attuned to the phenomena that I will study and the stories I will be hearing. I believe that I am better equipped now to interpret the deeper meanings in the stories that I will hear and to respect and value the journeys that others take. 
I hold dear what my father noted about war. Life has many choices we make as human beings to either focus on our differences or seek strengths from our common bonds. I thank my Norwegian great-grandfather for opening up the space for my grandmother to have a better life. I am glad she seized the opportunity. She was loved by her father. Did that make the difference for her? I realize that some people are like the Norwegian Freedom fighters. They create openings and spaces for others to crawl to safe places; they create opportunities to help others see their strengths, and to be successful. It is not o.k. to think that you are the only person who has had to make sense of these things. I reflect on what I learned from a study in Florida about schools that had build strong learning partnerships and those that had not (Acker-Hocevar et al., 2006/2005). Partnerships require thoughtful action and a shared sense of purpose that can lead to a broader understanding of community and self. Partners must be willing to acknowledge what they know and don't know as they share their stories and learn together. That is what makes the journey beautiful. And the picture that I thought I was in until this autoethnography was not me at all but my mother, my grandmother, my great grandmother, and my great-great grandmother. Why did I assume I was in the picture? I just wrote myself into it.

\section{Autoethnography II: Author B}

\section{Leaving, Transforming, and Expanding}

Long before the stories of first-generation college students interested me as a researcher, they served as a source of entertainment and intrigue. The first such tale that I recalled was my mother's account of how she left the sugar cane plantation on which she was raised, journeyed from the Hawaiian Islands to Kansas, and earned a degree in education at Emporia State Teacher's College in the late 1950s. After listening to the story multiple times as a young child, I knew it well. It started tragically, with the death of my Uncle Jimmy during the Korean War. What little money Jimmy had saved as a Marine, he bequeathed to Rosie who was his 15-year-old sister and my future mother. I can only speculate why he chose Rosie out of his eight siblings. Most likely it was because she was bright, feisty, and longed to explore life beyond the shores of the Garden Isle of Kauai. The story had its humorous and poignant plot twists. On one hand, there was the newly transplanted student's discovery in the dining hall that the fluffy white food called cottage cheese did not taste as delicious as it looked. On the other hand, just as Eliza Doolittle learned to hide her cockney accent under Henry Higgins' tutelage, Mom's Pidgin English gave way to proper pronunciation and grammar with the help of roommates from the mainland United States. That particular transformation was bittersweet; to become a part of this new collegiate community she had to set herself a part from family, friends and her heritage. Luckily, this separation from her family and community was neither total nor permanent. My mother's collegiate story ended happily due to careful scripting. Only after my mother had her college degree in hand and her high school sweetheart spent four years in the Air Force, did they marry. 
In the late $1970 \mathrm{~s}, \mathrm{my}$ father's first-generation college student story was added to the collection. The protagonist was older, in his 40s, and worked for the Federal Aviation Administration to support his family. I played a character in this particular tale. Indeed, I was one of the four school-age children who tiptoed around and spoke in hushed tones when it was time for Dad to study at his desk in our basement. As education expanded Dad's world, it also expanded ours. For example, my first visit to an art museum was the direct result of his having to complete an assignment for an art class. Moreover, although my dad majored in electrical engineering, we were introduced to graduate students and undergraduates in diverse disciplines like political science and physical therapy. This was because Dad would routinely invite the few students of Filipino or Hawaiian background whom he encountered on the campus of the University of Colorado at Boulder to our house to enjoy a home-cooked Asian meal. We were thrilled when Dad completed his college degree. Not only did we share in his accomplishment, but also we knew he would make good on his promise to get us a family dog once he finally finished school.

\section{Differences and Commonalities}

Undoubtedly, my parents' college stories influenced my own decision to go to my "dream school", the University of Notre Dame. Although I was a second-generation college student, I definitely could relate to some of their experiences as students of color and to their deliberate efforts to create a sense of belonging through friendships and extracurricular activities. When I attended Notre Dame in the late 1980s, the majority of students were white males. Although I do not know the exact number of Asian American students that were in my graduating class, a reasonable estimate would be fewer than 75 students out of 2000. (In 2010, 7.3 \% or 150 out of the 2065 freshman at Notre Dame were Asian Pacific American.) Perhaps the rarity of students of color at Notre Dame explained why the Irish-American priest at my aunt's parish on Kauai doubted that any member of our extended family was actually accepted at such a well-known Catholic university. He remained skeptical until I was introduced in person as undeniable proof! As for gender issues, one curious reminder that the institution had admitted its first female students less than fifteen years prior was the fact that the male students had personal laundry bundle service while the female students did their laundry in washers and dryers in their residence halls! Going to college in the wake of the civil rights movement and women's movement influenced my college experience and subsequent life decisions. What Stacey (1991) observed about young women in the late twentieth century resonated with my own experience: increased opportunities and a wide range of choices in a context of continuing discrimination and a lack of social and political support for those choices.

During my years at Notre Dame, there were ample opportunities to wonder how other students' backgrounds impacted their college experience. This seemed especially true of my senior year, when my closest friends and roommates were Morgan and Tierney (fictional names). Oftentimes it seemed as if Morgan, Tierney and I were from different worlds. I was a Filipino-American who grew up first in Longmont, Colorado and then in Lakewood, California a middle class community which was known as the archetypal post-World War II American suburb. Morgan was a Texan who was proud of her Scottish- and Irish-American heritage. Her father, a M.D., and her mother, a Ph.D., were 
both medical researchers. Morgan was pre-med and seemed especially savvy (and/or knew people who were savvy) about how to position herself for acceptance to medical school. Indeed, by her senior year Morgan had co-authored at least one refereed journal article!

Our roommate, Tierney, however, had perhaps the most compelling story because she was a first-generation college student. Tierney, an African-American, grew up a couple of hours from Notre Dame in Gary, Indiana. Unlike Morgan and I who were raised Catholic and attended Catholic schools, Tierney was Protestant and a product of public schools. She first learned about Notre Dame through some sort of college access program and had connected with some effective mentors based in residence life who helped her answer the "Where to go?" and "How to go?" questions that arose as she tried to navigate around the university. Tierney also had the emotional support of her mother. Sadly, her beloved mother died from complications of Lupus when Tierney was a sophomore. Thus, Tierney knew after her life after college would include not only securing her first job and repaying her student loans, but also helping her grandmother raise Tierney's two younger sisters. While we were more different than similar, Morgan, Tierney and I ultimately all persisted in our college education and at graduation both believed and felt the following phrase to be true: "We are ND"!

Upon examination, although my personal collection of stories from first-generation college students is diverse, common themes are woven throughout the individual accounts. First, education is something incredibly precious which improves both you as a person and your opportunities in life. As a result, you should set education as a goal and also savor the process. Second, obstacles are likely, but not insurmountable if you dare to dream, work hard, connect with people who will support you, and remain simultaneously open to change and true to yourself. Undoubtedly, the "moral" of these stories shape the hopes and expectations which I hold not only for the first-generation college students at our university but also my own children who are third-generation college.

\section{The Balance Simply Shifts}

Complementing the stories of important people in my life, the fields of psychology and education have provided me with ways to try to better understand why people decide to go to college and why they persist. Developmental psychology examines issues such as the nature and acquisition of knowledge, the construction of identity, personal change, life transitions, and the impact of social institutions on people (Miller, 2006). In general, constructing stories about one's life as one develops is a process by which an individual may integrate past experiences, current concerns and future prospects (Erikson, 1968; McAdams, 2001). The college context is likely a prime context for identity development including racial, ethnic identity development (e.g., Phinney, 2006; Syed, 2010; Syed \& Azmitia, 2009). Miller (2006) asserts that there are several selves that exist simultaneously and observes, "At one time, or in one context, one aspect of self may predominate, but other aspects emerge at other times and places. Over time certain aspects of self become stronger and more prevalent, and others diminish. Thus, a self, identity, ability of skill is multiple, fluid and ever changing; the balance simply shifts" ( $p$. 462). This certainly was true of my parents, my college roommates and me! 
Research with college students of color suggest perceptions of racial climate, involvement in diversity-related activities and connections not only within the college but also with external communities positively predict sense of belonging (Nuñez, 2009). As the sense of self becomes better defined, it is optimal if opportunities for a sense of belonging also exist (Maestas, Vaquera, \& Zehr, 2010). I think it wise to bear in mind the reciprocal influence between the student and their complex environment. Kagan's (1994) metaphor of a vine growing through a thick forest helps illustrate this. How is it that a student (or vine) grows in the forest of college? The vine's (student's) growth is fueled by its own inner processes. Yet, there is reciprocal influence. As it grows, the vine might change its form and the direction of its path in response to the forest (university, community, family, etc.). Concomitantly, its presence in the forest impacts the growth of other plants and trees and thus changes the forest itself. How can we recognize each student's assets and allows for a strength-based understanding of the college experience? How do I, my research partners, and other educators understand and attend to challenges faced by students and inquire which curricula, policies, and programs will help them access and succeed in college (Green, 2006)? With great curiosity, I continue to ponder these questions.

\section{Autoethnography III: Author C}

\section{The River}

The Columbia River flows quietly by our campus. At this point, the river is slow and deep and azure blue. Geese, cranes, and myriad other birds make their nests on the wooded island that sits mid-river. On a calm day, a brave or hungry deer swims out to the island to graze on new spring twigs. I sit on the campus lawn, gazing half mile across the island to the other side of the river. On the far side, I see huge vineyards crawling up the bank, straight green rows marching over the horizon in perfect cadence. They rise and spread across the rich alluvial soil swept here by millennia's upstream storms. To my eye, the grape rows appear closer together as they fall away into the distance, until all I see is a deep green carpet hugging the earth. Nearby, apple and cherry orchards fill most of the space not claimed by the grapes. Above me, a lone hawk circles high above the river. She is playing in the down drafts created by the frigid water. The river is cold even now, in late spring, chilled by melting Canadian snows.

\section{People}

My eyes drop back to vineyards. Looking more carefully, I see people bent over the vines, working slowly along each row. I know from my own work as a child in vineyards that the people I now see are tying loose vines up off the ground. They bend and tie the vines so the coming summer grapes will thrive, the wines will make, with the resulting reds and whites going to someone's table. I ponder that the river gives life to scenes like the one I now see, for hundreds of miles up and downstream from where I sit. Water, soil, fruit, vegetables, and people, all coming together to make a life because of the river. Now the sun is hot and bright on the water. It turns the waves and ripples to a bright white-silver. I stand, close my book, and return to the building. Time for class. 
Tonight's class is a masters' level course about social forces, societal values, and historical events that shape organizational policies and processes. Most of the students work in local schools as teachers, psychologists, counselors, or administrators. About half are male, and half are female. A little over one-third of the class members are students of color. All are working toward their educational leadership state certificate, or they are working on a master's degree in educational leadership.

The class session opens as Juan, (all names are fictitious) a masters' student who wants to be a principal, tells of an article he read in the New York Times (NYT), online. He begins by explaining that he teaches eighth grade math in a school that has $90 \%$ minority students, and a $95 \%$ mobility rate. The article he is talking about describes options open to schools that perform poorly on state and federally mandated tests. Juan starts quietly, but becomes more animated as he talks about federal Race to the Top (RttT) plans that will force schools like his to fire the principal and many of the teachers. Juan is a good student. He is articulate, critical, and passionate about improving schools. He explains that like schools in the NYT article, he teaches in a school that has announced the firing of the principal, and $60 \%$ of the teachers. The principal and most teachers in his school are highly committed to students, says Juan. He explains that most of his students are migrant worker children, who are in class only parts of the year. Almost all of his students speak Spanish at home. Although many students make good progress, Juan says that his school always scores low on state-wide tests.

Juan begins to tell his own story. My parents were migrant workers. They came here to work the vineyards and orchards. As a child I worked with them. They wanted me to attend school, so whenever we could, we planned our day's acreage so I could work before and after school, and attend school during the day. We all lived in a work camp. A bus came out to the camp each day. Four or five students, different ones each day, rode the bus. I was the first one in my family to attend school in the U.S. I am the first one to attend college. The discussion unfolds. He explains that in the school where he now works, many students, just as when he was growing up, attend class only when not needed in the fields. He says that current tests don't show how much these students do learn. The class is fascinated by his story. Other students speak up, adding their own views and perceptions. Some have had similar experiences. I listen. I am struck by the depth and passion evident in the students' thinking and understanding.

\section{Colleagues, Friends, and Self}

The next day, I relate the class events and discussion to two colleagues. They have had similar experiences in class. We continue a conversation that we've been having for several months about the growing population of students at our university, who, like Juan, are students of color and first-generation college students. The discussion is, and has been, passionate. We all sense that there is a huge opportunity and a great responsibility to understand more about students like Juan, and how they succeed in college.

As Kuo, Hagie, and Miller (2004) note, college students increasingly bring complex issues to campus and choose to manage their academic careers and personal lives in a variety of ways. Yet, these strategies for dealing with personal and academic challenges 
are the fundamental issues that colleges and universities need to explore in order to help their students succeed. (p.1) We begin to ask ourselves if students from traditionally underserved backgrounds bring issues and lives to campuses that are different than those of traditional students. It seems probable that universities tend to build programs and policies and practices that reflect the needs of more traditional, majority students (Zis, 2002).

At some point in our discussions, critical realizations and questions emerge. We know that students much like Juan have successfully navigated public schools, a bachelor's degree, and are now doing exceptional work as graduate students in our programs. Yet, we know that many students from less traditional groups who start college do not finish (Tinto, 1997).

Questions arise. How did Juan succeed? What does he know and do that those who make up the dismally high non-retention and non-graduation rates at many schools and colleges do not know?

Research has suggested that variables such as high school grade point average (GPA), leadership experience prior to attending college, and sibling success in college may be useful predictors in college retention and success of traditional student populations (Reason, 2003). However, as we begin exploring demographics of students at our campus, we wonder if those predictors may not work as well for the underserved population that compose almost $20 \%$ of our student body.

Our excitement grows as we try to understand what success strategies Juan and others may use to make school work for them. Could we identify success strategies that might help other students, and, perhaps influence university policy and practice in ways that may increase student success? What is student success? How do students define success? Do they define success differently than does the university?

\section{Self}

I am not a person of color, although many people in my family are ethnic minorities by genetics and culture, including nieces, nephews, daughter- in- law, brother- in- law, and my grandchildren. I know that some of my perspectives and the strong feelings that I bring to the discussion with my colleagues come from who my family is. When Juan talks of white students teasing him or mistreating him as a child, my mind goes to my grandchildren. I wonder if they have, or will, experience similar treatment. This thinking informs my interests in fairness and social justice, to be sure. Yet, in reflection, I am aware that I have always felt strongly about fairness. It was a strong value in my family, and one that my wife and I have tried to instill in our children, and their children.

I worked in the fields as a child. My family lived in a rural area where there were no migrant workers. So, as often happens in agricultural societies, basic agriculture work fell to children and young people. Interestingly, my wife also worked in her grandparents' fields, taking vegetables to a growers' market to sell each morning at 3:00 a.m. We have often pondered how this work may have changed and directed our lives and views. 
The work I did in the fields did not come from the intense necessity that brings people like Juan's family to the work camps and the vineyards. I suspect, though, that when Juan and others talk about not being able straighten up for hours after bending all day in the fields, or when they speak of not breathing well for days after inhaling too much pollen while picking fruit from peach trees, my memory reminds my back and lungs of similar days.

Moreover, I am a first-generation college student. As a child, and later as a college student, my parents and family supported my academic work. Like Juan, I was lucky to have parents that intuitively knew that going to school was a good thing, that reading was to be valued, and scarce resources of time and money should justifiably support their son's academic journey.

All these elements are components of who I am. For years I have been drawn to underserved students and their issues surrounding their success in schools. My work as a practitioner (teacher, counselor, principal, superintendent) seemed always to take me to schools where underserved students composed significant portions of the student population.

I enjoyed working in low income, high risk, schools. In retrospect, it doesn't feel like I was there to right a wrong, or fix a problem. Missionary work never appealed much to me. Rather, perhaps it was that so called underserved students were those with whom I was most comfortable, who trusted me most, and in whom I perhaps saw parts of myself. Many of my life's great experiences came from those times.

When I came to this campus two years ago as a clinical assistant professor, the Dean said to me that we were in an area that had a high population of underserved students, and one of the university's expectations was for me to recruit more of these students into the educational leadership program. My path had taken me again, quite unexpectedly, to a place where I could be at home with my interests. I began to see that what I had for many years called an interest in underserved students, was in fact, a passion.

By some great stroke of luck, I found myself working side by side with colleagues who in their heart of hearts hold the same passion for what has been called social justice, which I hold in mine. Further, I began to see they are brilliant, and hold deeply grounded understandings of the issues surrounding the growing number of underserved students, like those at our university. I became aware that I also value them as friends, and as such their ideas take on all the more influence in my life and my thinking. To ignore the effect that collegial friendship has on my thinking is to be naïve to the great power that such relationships generate.

As the year goes on, I become very excited about the opportunities that our collegial partnership may have to create deeper understandings for my teaching, scholarship, and perhaps for the organization and function of the university. Could our ideas and findings have implications for our practice and teaching? As our conversations continue, I become aware that my colleagues are interested in these concepts. Their thinking and 
voices begin to influence and encourage my own thoughts about how we might explore students' success strategies.

Who we are as people, researchers, and colleagues, cannot be ignored. Pulitzer Prize winning author Wallace Stegner describes how the sum of who we are influences our perceptions and thinking, in Wolf Willow, his account of growing up on the Canadian frontier. As he looks at his place of childhood, but as an adult instead of a child, he says, "It is a lesson in how peculiarly limited a child's sight is: he sees only what he can see. Only later does he learn to link what he sees with what he already knows, or has imagined, or heard, or read, and so comes to make perception serve inference" (p. 22).

As our research group has explored our own experiences and perceptions, we have perhaps become better able to understand how we view students in our study, and how we might construct a framework that would help us understand underserved students' success strategies. Integral with one's own experiences, is his or her academic training and life of scholarship.

I have long been interested in the ways in which people make sense of new organizations and new environments. Scholars such as Weick (2005, 1999, 1993, and 1988), Weick, Sutcliffe, and Obstfeld (2005), Ogawa, Johnson, Talbot, et al (2002); Shields and Dervin, (1993), Green, (2006), Matthews and Crow, (2010) have extended the literature in this area. In the sensemaking view, a person's experiences either prepares them for a new environment, or, if those experiences and inferences are inadequate to create the complexity that leads to new understandings, the person experiences confusion, and attempts to place the dynamics of the new environment in a context that can be understood.

Using sensemaking is only one way to begin the process of asking students to share with the researchers their stories. I have delved into my own story, as it relates to who I am and how I might see student experiences and understand their meanings. Doing so has illuminated for me ways that may be more open, more transparent, more connected, and more accurate in capturing what underserved students have to say about how they develop their own success strategies in a university setting. 